\title{
Nutrient requirements for irrigated lucerne in Central Otago
}

\author{
L.C. SMITH ${ }^{1}$, K.D. TRAINOR ${ }^{2}$ and J.D. MORTON ${ }^{3}$ \\ ${ }^{1}$ AgResearch, Woodlands Research Station, RD 1, Invercargill \\ ${ }^{2}$ Southtech, 2 Thompson Street. Alexandra \\ ${ }^{3}$ Ballance Agri-Nutrients, PO Box 2290, Hastings \\ chris.smith@agresearch.co.nz
}

\begin{abstract}
Two field trials were commenced in September 2000 on newly sown irrigated lucerne near Tarras in Central Otago. The first trial measured the effects of phosphorus (P) $(0,30,60,120 \mathrm{~kg} \mathrm{P} / \mathrm{ha})$ and potassium $(\mathrm{K})(0,50$, $100,200 \mathrm{~kg} \mathrm{~K} / \mathrm{ha}$ ) fertiliser applications while the second trial determined nitrogen $(\mathrm{N})$ requirements for lucerne establishment. Initial soil test levels $(0-75$ $\mathrm{mm}$ ) were $\mathrm{pH} 5.6$, Olsen P $15 \mu \mathrm{g} / \mathrm{ml}$; quicktest (QT) K 6 and sodium tetra-phenol-boron extractable K (TBK) 3.1. Lucerne production averaged $9.5 \mathrm{t}$ dry matter $(\mathrm{DM}) / \mathrm{ha}$ in the establishment year, $15.6 \mathrm{t} \mathrm{DM} /$ ha in Year 2 and $14.8 \mathrm{t} \mathrm{DM} / \mathrm{ha}$ in Year 3. There were no annual DM responses to any of the three fertilisers applied regardless of the rate of application. Despite the control mean annual herbage $\mathrm{P}$ concentrations being within the optimum range of $0.20-0.25 \%$ the application of $\mathrm{P}$ fertiliser significantly increased the $\mathrm{P}$ concentrations $(\mathrm{P}<0.001)$ in Years 1 and 2. The herbage $\mathrm{K}$ concentrations were above required concentrations $(1.5-1.8 \%)$ for all harvests, and were only affected by $\mathrm{K}$ fertiliser application in Year 3. The lucerne crop removed between 300 and $600 \mathrm{~kg} \mathrm{~N} / \mathrm{ha} /$ year, 230 to $300 \mathrm{~kg} \mathrm{~K} / \mathrm{ha} /$ year and 25 to $40 \mathrm{~kg} \mathrm{P} / \mathrm{ha} /$ year. Biological $\mathrm{N}$ fixation appears to be replacing the $\mathrm{N}$ removed as the lucerne did not respond to applied $\mathrm{N}$ and the soil $\mathrm{N}$ levels were maintained throughout the 3 years. The removal of nutrients such as $\mathrm{P}$ and $\mathrm{K}$, to a greater level than fertiliser applied, under a hay regime has implications for the longevity of the stand. This is highlighted for $\mathrm{P}$ on the $\mathrm{P}$ plots with the soil Olsen P levels dropping to $<8 \mu \mathrm{g} / \mathrm{ml}$ for the $0-75 \mathrm{~mm}$ soil layer and $<5 \mu \mathrm{g} / \mathrm{ml}$ for the $0-150 \mathrm{~mm}$ soil layer by the third year. Potassium reserves in the soil also declined, highlighting slow depletion under hay cropping. It would appear that $0-75 \mathrm{~mm}$ Olsen P levels of at least $12-15 \mu \mathrm{g} / \mathrm{ml}$ and $0-150 \mathrm{~mm}$ Olsen P levels of $10-12$ $\mu \mathrm{g} / \mathrm{ml}$ are required for optimum production ( $95 \%$ of maximum) at this site. Regular monitoring of soil and plant nutrient levels is recommended to ensure fertiliser inputs are sufficient to maintain maximum production.
\end{abstract}

Key words: lucerne, irrigation, nutrient requirements, phosphorus fertiliser, potassium fertiliser, nitrogen fertiliser.

\section{Introduction}

The Central Otago climate is characterised by low rainfall and extremes of temperature. In such a climate lucerne (Medicago sativa L.) can have growth advantages, due to its deep rooting nature, and if managed correctly can outproduce normal ryegrass/ white clover pasture (Douglas 1986; Douglas et al. 1987; Greenwood \& Sheath 1982; Moot 2012). In such situations lucerne is commonly used as a specialist crop for hay production over the spring and summer, then grazed in autumn. Dryland lucerne can produce as little as $2 \mathrm{t} \mathrm{DM} / \mathrm{ha}$ or as much as $17 \mathrm{t} \mathrm{DM} / \mathrm{ha}$, depending on rainfall (Douglas 1986; Mills et al. 2008; Risk \& Smith 1992). Fertiliser requirements of lucerne are well known (Harris et al. 1967; Risk \& Smith 1992; Stephen 1970), with the fertiliser industry using this knowledge to create a specialist lucerne fertiliser mix containing $5.5-6 \%$ P, $12-15 \%$ K and $13-15 \%$ S. Generally farmers in Central Otago have applied $250-375 \mathrm{~kg} /$ ha of this lucerne mix to dryland crops yielding 6-9 $\mathrm{t} \mathrm{DM} / \mathrm{ha}$, resulting in application rates of $15-23 \mathrm{~kg} \mathrm{P} /$ ha, 30-45 kg K/ha and 40-60 kg S/ha. However Risk \& Smith (1992) suggested that in some areas the need for $\mathrm{P}$ and $\mathrm{K}$ compared to $\mathrm{S}$ is greater than these rates supply. This is likely to be particularly so where the lucerne is irrigated, as in this situation it can produce considerably more, with yields in excess of $20 \mathrm{t} \mathrm{DM} / \mathrm{ha}$ being recorded (Douglas 1986; Hoglund et al. 1974). Some farmers are also starting to consider whether N as well as irrigation can be used in the establishment phase to improve crop vigour and performance. Janson (1975) found that irrigation substantially increased production in the establishment year, with no long-term effect on later years. Hoglund et al. (1974) found that $\mathrm{N}$ applied in the spring did not increase yields of irrigated lucerne, but did increase yields when applied in the summer and autumn. They suggested that the $\mathrm{N}$ from the legume-rhizobium symbiosis over autumn may have been insufficient for the plant's needs and hence limited production.

This paper reports on the response to N, P and $\mathrm{K}$ fertilisers by a newly established lucerne stand under irrigation. 


\section{Methods}

Site

The trial site was located on border dyke irrigated river flats on Grandview Station between Tarras and Hawea in Central Otago. While dates and irrigation volumes are not available, it is known that these flats were regularly irrigated on an as-required basis to avoid any "drought stress". The soil was a Gladbrooke moderately deep sandy loam, classified as a Typic Immature Pallic Soil. The trial area was cultivated out of pasture in winter 2000 , following late autumn application of glyphosate (Roundup $^{\mathrm{TM}}$ ) and glufosinate-ammonium (Buster ${ }^{\mathrm{TM}}$ ) at recommended rates. Following cultivation the trial area was sown with inoculated lucerne (Medicago sativa L.) cv. 'Kaituna'. Initial soil test results $(0-75 \mathrm{~mm}$; October 2000) were $\mathrm{pH} 5.6$, Olsen P $15 \mu \mathrm{g} / \mathrm{ml}$; quicktest (QT) K 6 and sodium tetra-phenol-boron extractable K (TBK) 3.1 .

\section{Design}

Design of the main trial was a $\mathrm{P}(0,30,60,120 \mathrm{~kg} \mathrm{P} / \mathrm{ha} /$ year as triple superphosphate (TSP) $) \times \mathrm{K}(0,50,100$, $200 \mathrm{~kg} \mathrm{~K} / \mathrm{ha} /$ year as potassium chloride $(\mathrm{KCl})$ ) factorial with two replicates. Both these fertilisers were applied as two equal applications, the first at the commencement of the trial (October 2000 or August each year) with the second application following the first harvest each season. A second trial with four rates of $\mathrm{N}$ applied as urea with four replicates was laid down adjacent to the main trial. As the basal fertiliser for the $\mathrm{N}$ trial was the same as the top rate in the $\mathrm{P} \times \mathrm{K}$ trial, two of the $\mathrm{N}$ trial replicates shared plots $(0 \mathrm{~N})$ with the $\mathrm{P} \times \mathrm{K}$ trial. The $\mathrm{N}$ fertiliser treatment in the establishment year was 010,20 and $40 \mathrm{~kg} \mathrm{~N} / \mathrm{ha}$ applied in two applications, the first at plant emergence, the second following the first harvest. The $\mathrm{N}$ treatments in Years 2 and 3 were applied in August and following each harvest at a total application rate of $0,30,60$ and $120 \mathrm{~kg} \mathrm{~N} /$ ha/year. Plot size was $3 \mathrm{~m} \times 1 \mathrm{~m}$.

Basal sulphur (50 $\mathrm{kg} \mathrm{S} / \mathrm{ha}$ as gypsum), sodium tetraborate $(5.5 \mathrm{~kg} / \mathrm{ha})$ and sodium molybdate $(200$ $\mathrm{g} / \mathrm{ha}$ ) were applied at the commencement of the trial (October 2000). Further applications of sulphur (50 kg $\mathrm{S} /$ ha as gypsum) were applied twice each year with the $\mathrm{P}$ and $\mathrm{K}$ treatments. Because of the low $\mathrm{pH}$ after year 2, $2.5 \mathrm{t} / \mathrm{ha}$ of lime was applied to the trial in July 2002.

\section{Measurements}

The lucerne was cut at the hay stage (early flowering). There were three harvests in Year 1 (establishment year) and four harvests in subsequent years. The cut herbage was weighed, with a subsample dried at $60^{\circ} \mathrm{C}$ before being analysed for $\mathrm{N}, \mathrm{P}$ and $\mathrm{K}$ by standard analytical methods. Annual average nutrient concentrations in the lucerne were calculated from total annual losses divided by total annual production. Soil samples $(0-75$ $\mathrm{mm})$ were collected from each plot in August 2001, June 2002 and June 2003, while deeper samples (0-150 $\mathrm{mm})$ were collected at the June 2002 and June 2003 samplings.

\section{Statistical analysis}

All data were analysed by analysis of variance (ANOVA) using GENSTAT v16. Relative yield curves were fitted where an asymptote could be obtained using Mitscherlich equations following the method of Sinclair et al. (1997).

\section{Results and discussion}

In the establishment year the lucerne produced $9.5 \mathrm{tDM} /$ ha with no significant yield increases due to fertiliser application. In Years 2 and 3 lucerne production exceeded $15 \mathrm{t} \mathrm{DM} / \mathrm{ha}$, achieving a maximum of $17 \mathrm{t}$ $\mathrm{DM} /$ ha with applied $\mathrm{N}$. These yields are lower than those reported under irrigation elsewhere (24.0 to 28.2 t DM/ha; Hoglund et al. 1974), but somewhat higher than those produced with dryland lucerne in Southland (3-10 t DM/ha; Risk \& Smith 1992). Moot et al. (2012) did achieve similar yields in the establishment year (9.6-9.9 t DM/ha) with dryland lucerne in Canterbury, however this occurred in a year where rainfall was adequate throughout the season. Mills et al. (2008) also measured yields of dryland lucerne in Canterbury ranging from 9.7 to $17.3 \mathrm{tDM} /$ ha over 5 years depending on rainfall patterns. One of the factors affecting lucerne yield can be the effect of soil moisture, or lack of it, on annual yields. The irrigation supplied to this trial, on an as-required basis, meant that the plants were never under moisture stress. The similar production in years 2 and 3 at this site (15-16 t DM/ha/year) shows that irrigation is one tool to reduce the variation in lucerne production resulting from soil moisture limitations.

The application of $\mathrm{P}$ and $\mathrm{K}$ fertilisers had only small and statistically insignificant effects on lucerne growth (Table 1). Nitrogen fertiliser application did not benefit lucerne establishment in Year 1 as production dropped from $9.8 \mathrm{t} \mathrm{DM} /$ ha for the control to $9.2 \mathrm{t} \mathrm{DM} /$ ha with $40 \mathrm{~kg} \mathrm{~N} / \mathrm{ha}(\mathrm{P}>0.05)$. As the lucerne was sown directly after cultivation of pasture, it is likely that the soil mineral $\mathrm{N}$ was higher than if it had gone through a cropping rotation and therefore soil $\mathrm{N}$ supply was not likely to limit establishment.

Fertiliser application increased the herbage $\mathrm{P}$ concentrations (Table 2), but had little effect on $\mathrm{K}$ or $\mathrm{N}$ concentrations. All the average concentrations $(\mathrm{N}, \mathrm{P}$ and $\mathrm{K}$ ) were at or above the optimum range initially (N 3.0-3.5\%; P $0.20-0.25 \%$; K $1.5-1.8 \%$; Cornforth \& Sinclair 1984). However, lucerne herbage $\mathrm{P}$ concentrations dropped to below the optimum level of $0.20-0.25 \%$ for the autumn harvests in Years 2 
and 3 (data not shown) for the control and $30 \mathrm{~kg} \mathrm{P} /$ ha application rates only. $\mathrm{P}$ application did increase $\mathrm{N}$ concentration in Year 1, although this occurred only at the higher application rates.

The lucerne crop removed between 300 and $600 \mathrm{~kg}$ $\mathrm{N} / \mathrm{ha} /$ year, 230 to $300 \mathrm{~kg} \mathrm{~K} / \mathrm{ha} /$ year and 25 to $40 \mathrm{~kg} \mathrm{P} /$ ha/year (Figure 1). The $\mathrm{N}$ removal figures are in line with other workers (Gault et al. 1995; Hoglund et al. 1974), but there is a lack of recent data in the literature on $\mathrm{P}$ and $\mathrm{K}$ removal. While there were no treatment effects on $\mathrm{N}$ and $\mathrm{K}$ removal, there was a significant effect of $\mathrm{P}$ application on $\mathrm{P}$ removal in Year $2(\mathrm{P}=$ 0.014; Figure 1). Considering the lack of DM response, it is likely that this was due to the luxury uptake of $\mathrm{P}$ by the herbage. The ability of lucerne to fix considerable amounts of $\mathrm{N}$ (Brockwell et al. 1995; Gault et al. 1995) means that the use of $\mathrm{N}$ fertiliser is unlikely to result in increased yields despite the removal of up to $600 \mathrm{~kg} \mathrm{~N} / \mathrm{ha}$. Indeed after 3 years the total soil $\mathrm{N}$ in the control plots was $0.25 \%$ to $75 \mathrm{~mm}$ and $0.22 \%$ to $150 \mathrm{~mm}$ soil depth, while for the $200 \mathrm{~N}$ plots they were 0.25 and $0.23 \%$ respectively. The removal of nutrients, particularly $\mathrm{K}$ and $\mathrm{P}$, under a hay regime can have implications for the longevity of the stand. Harris et al. (1967) found that as the stand aged the requirements for
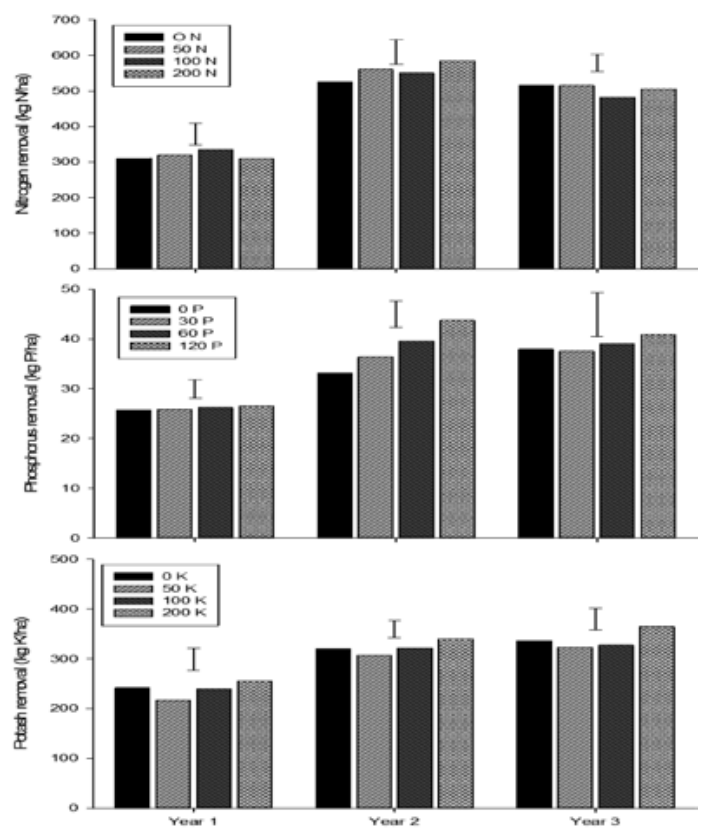

Figure 1 Effect of fertiliser application on the removal of $\mathrm{N}$, $\mathrm{P}$ and $\mathrm{K}$ in irrigated lucerne in Central Otago. Bars indicate LSD 0.05 .

Table 1 Annual and total production results from the Grandview lucerne trials ( $t \mathrm{DM} / \mathrm{ha})$. The least significant difference $\left(\mathrm{LSD}_{05}\right)$ at the $\mathrm{P}<0.05$ is given along with the F-statistic for fertiliser comparison.

\begin{tabular}{|c|c|c|c|c|}
\hline & $\begin{array}{c}\text { Year } 1 \\
2000-2001\end{array}$ & $\begin{array}{c}\text { Year } 2 \\
\text { 2001-2002 }\end{array}$ & $\begin{array}{c}\text { Year } 3 \\
2002-2003\end{array}$ & Total \\
\hline \multicolumn{5}{|l|}{ P x K Trial } \\
\hline P 0 & 9.8 & 14.8 & 14.2 & 38.9 \\
\hline 30 & 9.3 & 15.6 & 14.5 & 39.4 \\
\hline 60 & 9.8 & 15.8 & 15.2 & 40.8 \\
\hline 120 & 9.1 & 16.2 & 15.1 & 40.5 \\
\hline $\mathrm{LSD}_{05}$ & 1.2 & 2.4 & 1.3 & 2.6 \\
\hline F-statistic & 0.524 & 0.626 & 0.407 & 0.386 \\
\hline $\mathrm{Ko}$ & 9.8 & 16.0 & 14.6 & 40.3 \\
\hline 50 & 8.8 & 15.5 & 14.0 & 38.2 \\
\hline 100 & 9.4 & 15.7 & 15.1 & 40.1 \\
\hline 200 & 10.0 & 15.3 & 15.5 & 40.8 \\
\hline $\mathrm{LSD}_{05}$ & 1.2 & 2.4 & 1.3 & 2.6 \\
\hline F-statistic & 0.179 & 0.958 & 0.125 & 0.206 \\
\hline $\mathrm{P} \times \mathrm{K} F$-statistic & 0.489 & 0.961 & 0.855 & 0.651 \\
\hline \multicolumn{5}{|l|}{$\mathbf{N}$ Trial } \\
\hline No & 9.8 & 16.5 & 16.2 & 42.4 \\
\hline 10 & 9.7 & 16.8 & 15.7 & 42.2 \\
\hline 20 & 9.5 & 17.0 & 15.5 & 42.1 \\
\hline 40 & 9.2 & 16.5 & 16.4 & 42.0 \\
\hline $\mathrm{LSD}_{05}$ & 1.4 & 1.7 & 1.7 & 2.5 \\
\hline F-statistic & 0.781 & 0.842 & 0.630 & 0.985 \\
\hline
\end{tabular}


$\mathrm{K}$ and $\mathrm{P}$ both increased, probably due to the draw-down of soil reserves with time.

The application of $\mathrm{P}$ fertiliser significantly increased the soil Olsen P (Table 3), though only at the highest application rate in the first year. However by Year 3, all application rates significantly increased the $0-75 \mathrm{~mm}$ Olsen P, but only the 60 and $120 \mathrm{~kg} \mathrm{P} /$ ha rates increased the $0-150 \mathrm{~mm}$ Olsen P. It appears that at least $30 \mathrm{~kg} \mathrm{P} /$ ha was required to maintain an Olsen $\mathrm{P}$ of $13-18 \mu \mathrm{g} /$ $\mathrm{ml}$ at $0-75 \mathrm{~mm}$, while where no $\mathrm{P}$ was applied Olsen $\mathrm{P}$ levels steadily dropped.

Despite the lack of DM responses at this site a Mitscherlich curve was able to be fitted for $\mathrm{P}$ yield $\mathrm{v}$ soil $\mathrm{P}\left(\mathrm{r}^{2}=0.816 ; \mathrm{P}=0.007\right)$ but not to $\mathrm{K}$ yield $\mathrm{v}$ soil $\mathrm{K}$. The relationship so produced between Olsen $\mathrm{P}$ and relative yield (RY) for the lucerne (Figure 2) indicates that for a $0-75 \mathrm{~mm}$ soil test optimum production $(95 \%$ of maximum) would occur at an Olsen P of $15 \mu \mathrm{g} / \mathrm{ml}$. While this is similar to that found by Risk \& Smith (1992) for dryland lucerne, it is somewhat lower than the target range for clover based pastures $(20-30 \mu \mathrm{g} /$

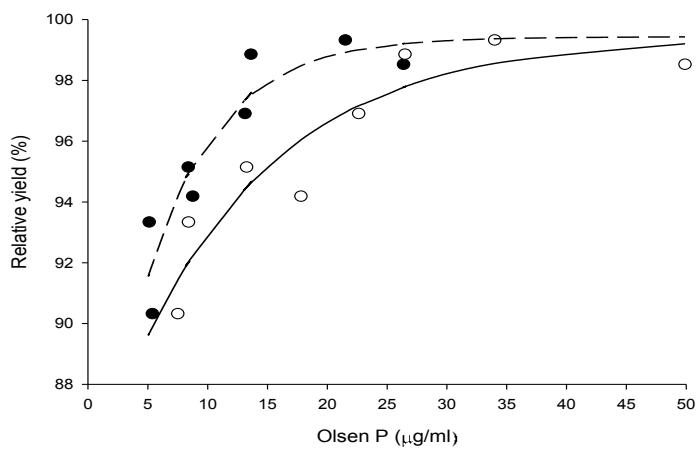

Figure 2 Relationship between lucerne relative yields in years 2 and 3 and soil Olsen $P$ for both $0-75$ $\mathrm{mm}$ sample depth ( $O$ Solid line) and 0-150 mm sample depth ( dashed line)

$\mathrm{ml}$; Morton \& Roberts 2009; 26-30 $\mu \mathrm{g} / \mathrm{ml}$; Edmeades et al. 2006) on sedimentary soils. Both these ranges, however, were developed using $97 \% \mathrm{RY}$ as their measure of optimum production, which if applied

Table 2 Effect of fertiliser application on annual yield weighted mean lucerne chemical concentrations (\%). Optimum levels are $\mathrm{N}$ 3.0- 3.5; P 0.20-0.25 and K 1.5- 1.8 (Cornforth \& Sinclair 1984). The least significant difference $\left(\mathrm{LSD}_{05}\right)$ at the $\mathrm{P}<0.05$ is given along with the F-statistic for fertiliser comparison (bold if significant).

\begin{tabular}{|c|c|c|c|c|c|c|c|c|c|}
\hline & \multicolumn{3}{|c|}{$\begin{array}{c}\text { Year } 1 \\
2000-2001\end{array}$} & \multicolumn{3}{|c|}{$\begin{array}{c}\text { Year } 2 \\
\text { 2001-2002 }\end{array}$} & \multicolumn{3}{|c|}{$\begin{array}{c}\text { Year } 3 \\
\text { 2002-2003 }\end{array}$} \\
\hline & $\mathbf{N}$ & $\mathbf{P}$ & $\mathbf{K}$ & $\mathbf{N}$ & $\mathbf{P}$ & $\mathbf{K}$ & $\mathbf{N}$ & $\mathbf{P}$ & $\mathbf{K}$ \\
\hline \multicolumn{10}{|l|}{ P x K Trial } \\
\hline P 0 & 3.13 & 0.26 & 2.47 & 3.44 & 0.23 & 2.16 & 3.11 & 0.27 & 2.25 \\
\hline 30 & 3.13 & 0.28 & 2.52 & 3.21 & 0.23 & 2.07 & 3.22 & 0.26 & 2.31 \\
\hline 60 & 3.42 & 0.27 & 2.52 & 3.32 & 0.25 & 2.08 & 3.15 & 0.26 & 2.26 \\
\hline 120 & 3.20 & 0.29 & 2.52 & 3.42 & 0.27 & 2.01 & 3.20 & 0.27 & 2.33 \\
\hline $\mathrm{LSD}_{05}$ & 0.16 & 0.016 & 0.26 & 0.23 & 0.02 & 0.23 & 0.28 & 0.05 & 0.25 \\
\hline F-statistic & 0.005 & 0.009 & 0.960 & 0.153 & $<0.001$ & 0.582 & 0.823 & 0.933 & 0.876 \\
\hline $\mathrm{KO}$ & 3.21 & 0.29 & 2.47 & 3.26 & 0.25 & 2.02 & 3.29 & 0.27 & 2.31 \\
\hline 50 & 3.25 & 0.27 & 2.45 & 3.27 & 0.24 & 1.99 & 3.15 & 0.26 & 2.31 \\
\hline 100 & 3.29 & 0.28 & 2.56 & 3.40 & 0.25 & 2.07 & 3.07 & 0.26 & 2.17 \\
\hline 200 & 3.13 & 0.26 & 2.55 & 3.46 & 0.24 & 2.24 & 3.16 & 0.26 & 2.36 \\
\hline $\mathrm{LSD}_{05}$ & 0.16 & 0.015 & 0.26 & 0.23 & 0.02 & 0.23 & 0.28 & 0.05 & 0.25 \\
\hline F-statistic & 0.219 & 0.023 & 0.748 & 0.204 & 0.796 & 0.140 & 0.447 & 0.971 & 0.417 \\
\hline $\mathrm{P} \times \mathrm{K}$ F-statistic & 0.143 & 0.385 & 0.536 & 0.286 & 0.498 & 0.962 & 0.832 & 0.999 & 0.082 \\
\hline \multicolumn{10}{|l|}{ N Trial } \\
\hline No & 3.18 & 0.27 & 2.52 & 3.22 & 0.26 & 2.10 & 3.18 & 0.30 & 2.52 \\
\hline 10 & 3.30 & 0.27 & 2.54 & 3.34 & 0.29 & 2.14 & 3.30 & 0.31 & 2.42 \\
\hline 20 & 3.51 & 0.29 & 2.61 & 3.23 & 0.25 & 2.13 & 3.11 & 0.30 & 2.45 \\
\hline 40 & 3.37 & 0.29 & 2.57 & 3.56 & 0.27 & 2.19 & 3.10 & 0.30 & 2.54 \\
\hline $\mathrm{LSD}_{05}$ & 0.48 & 0.02 & 0.16 & 0.37 & 0.02 & 0.21 & 0.38 & 0.03 & 0.21 \\
\hline$F$-statistic & 0.495 & 0.097 & 0.676 & 0.192 & 0.020 & 0.815 & 0.626 & 0.745 & 0.523 \\
\hline
\end{tabular}


to Figure 2 would give a critical Olsen P value of $22 \mu \mathrm{g} / \mathrm{ml}$ for the $0-75 \mathrm{~mm}$ sample depth. While this at the lower end of these target ranges for clover based pastures $(20-30 \mu \mathrm{g} / \mathrm{ml})$ on sedimentary soils, the lack of response to $\mathrm{P}$ fertiliser could easily explained by the deeper rooting characteristics of the lucerne compared to white clover, enabling nutrient uptake from a greater volume of soil. In addition the lucerne was grown as a monoculture and as such would not have suffered from competition with ryegrass for $\mathrm{P}$ as would happen to clover in a mixed sward.

For the $0-150 \mathrm{~mm}$ soil test optimum production $(95 \%$ of maximum) occurred at an even lower Olsen P of $9 \mu \mathrm{g} / \mathrm{ml}$. While the present recommendation is for $0-150 \mathrm{~mm}$ soil analysis where lucerne is grown, in situations where such data is lacking the relationship between Olsen $\mathrm{P}$ for the two soil depths (Figure 3) could be used as a guide to $P$ fertiliser requirements. However this relationship may be site/soil type specific and could possibly be different for another site or soil type.

There were small increases in soil QT K as a result of $\mathrm{K}$ fertiliser application, with these being significant in Years 2 and 3 only at the $200 \mathrm{~kg} \mathrm{~K} / \mathrm{ha}$ application rate. The lack of response to $\mathrm{K}$ fertiliser despite soil QT K levels dropping below the recommended value of 6 for lucerne production (Risk \& Smith 1992) could not be fully explained. The trials summarised by Risk \& Smith (1992) were conducted on Oreti soils which are known to have low reserve $\mathrm{K}$ status. In contrast the trial reported here was conducted on an immature Pallic soil with a reserve $\mathrm{K}$ (TBK) of 2.5. This reserve $\mathrm{K}$ was sufficient to supply all the lucerne plants requirements as Edmeades et al. (2010) suggest that a TBK of 1 would give $97 \%$ of maximum

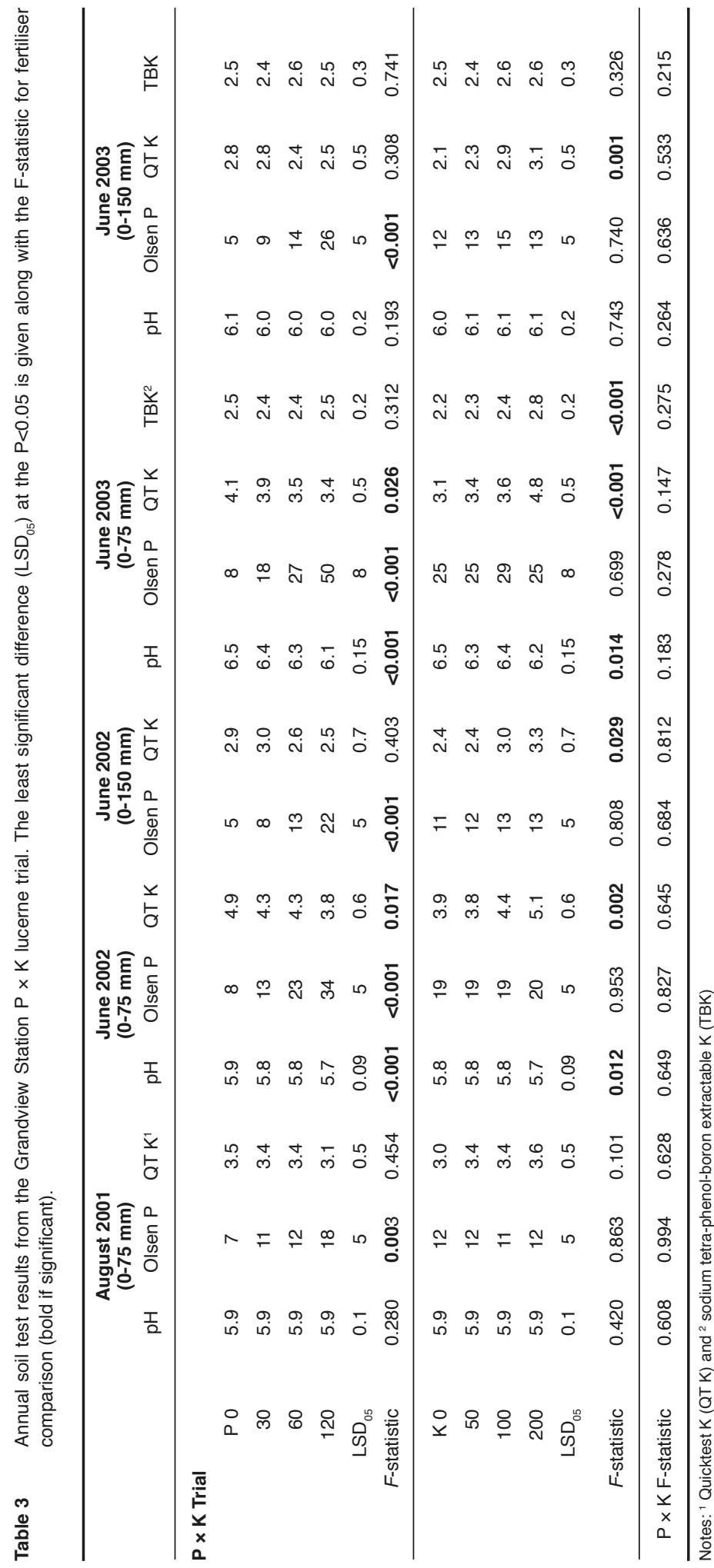




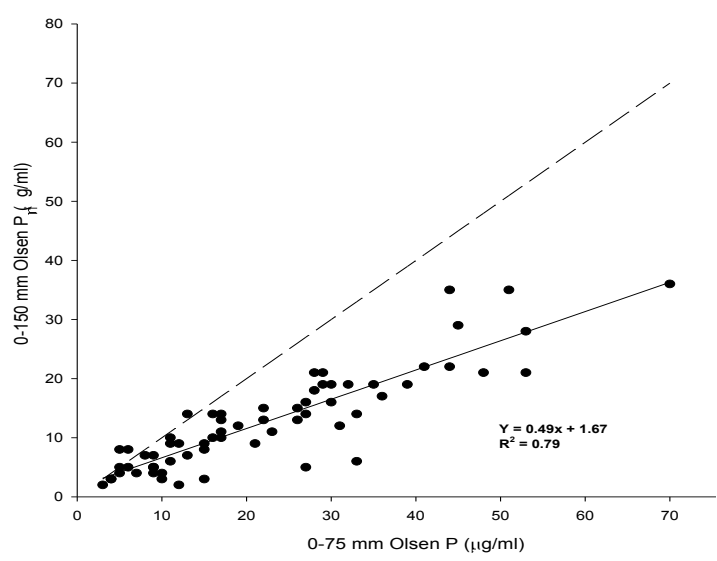

Figure 3 Relationship between the $0-75 \mathrm{~mm}$ soil Olsen $\mathrm{P}$ and the $0-150 \mathrm{~mm}$ soil Olsen P. The dashed line shows the 1:1 relationship.

production. It is also possible that, as suggested by Carey \& Metherell (2003) and Edmeades et al. (2010), the lucerne plants were extracting $\mathrm{K}$ from below the soil sampling depth of $150 \mathrm{~mm}$. Indeed lucerne roots have been measured down to $1 \mathrm{~m}$ within one year of establishment (Bell 2005; Gault et al. 1995) therefore one must expect that nutrients were being extracted to that depth.

\section{Conclusion}

The lack of DM production responses to $\mathrm{P}$ and $\mathrm{K}$ in this trial are in agreement with the current fertiliser recommendations for lucerne considering the initial soil fertility of the site. This is true for both soil and herbage nutrient concentrations. The lucerne crop is drawing down on soil $\mathrm{P}$ and $\mathrm{K}$ reserves where nutrients removed by the crop are greater than fertiliser nutrients applied, these being the control treatment for $\mathrm{P}$ and all treatments for $\mathrm{K}$. This has shown itself to be unsustainable for $\mathrm{P}$ in particular, with the soil Olsen P levels dropping from 15 to $8 \mu \mathrm{g} / \mathrm{ml}$ for the $0-75 \mathrm{~mm}$ soil layer and $5 \mu \mathrm{g} /$ $\mathrm{ml}$ for the $0-150 \mathrm{~mm}$ soil layer on the $0 \mathrm{P}$ plots. Even where $30 \mathrm{~kg} \mathrm{P} / \mathrm{ha}$ is applied, the amount of $\mathrm{P}$ removed in the herbage has resulted in this application barely maintaining Olsen P levels. Despite the soil QT K dropping below the recommended level of 6 the lack of DM response indicates that at this site the reserve $\mathrm{K}$ (TBK) is sufficient to supply the plant requirements at this time. However regular monitoring of soil and plant nutrient levels is recommended to ensure fertiliser inputs are sufficient to maintain maximum lucerne production and soil nutrient levels. There appears to be no advantage to applying fertiliser $\mathrm{N}$ at this site.

\section{ACKNOWLEDGMENTS}

Thanks to Colin Kane, Grandview Station for his support of this trial. This work was funded by Ballance Agri-Nutrients.

\section{REFERENCES}

Bell, L.W. 2005. Relative growth rate, resource allocation and root morphology in the perennial legumes, Medicago sativa, Dorycnium rectum and $D$. hirsutum grown under controlled conditions. Plant and Soil 270: 199-211.

Brockwell, J.; Gault, R.R.; Peoples, M.B.; Turner, G.L.; Lilley, D.M.; Bergersen, F.J. 1995. N fixation in irrigated lucerne grown for hay. Soil Biology and Biochemistry 27: 589-594.

Carey, P.W.; Metherell, A.W. 2003. Monitoring longterm changes in reserve potassium in some New Zealand soils using a modified sodium tetraphenylboron method. New Zealand Journal of Agricultural Research 46: 199-213.

Cornforth, I.S.; Sinclair, A.G. 1984. Fertiliser and lime recommendations for pastures and crops in New Zealand. 3rd revised edition. Ministry of Agriculture and Fisheries, Wellington New Zealand

Douglas, J.A. 1986. The production and utilization of lucerne in New Zealand. Grass and Forage Science 41: 81-128.

Douglas, M.H.; Brash, D.W.; Barratt, B.I.P.; Keoghan, J.M. 1987. Successful lucerne growing in inland Otago. Proceedings of the New Zealand Grassland Association 48: 193-197.

Edmeades, D.C.; Metherell, A.K.; Waller, J.E.; Roberts, A.H.C.; Morton, J.D. 2006. Defining the relationships between pasture production and soil $\mathrm{P}$ and the development of a dynamic P model for New Zealand pastures: a review of recent developments. New Zealand Journal of Agricultural Research 49: 207-222.

Edmeades, D.C.; Morton, J.D.; Waller, J.E.; Metherell, A.K.; Roberts, A.H.C.; Carey, P.W. 2010. The diagnosis and correction of potassium deficiency in New Zealand pastoral soils: a review. New Zealand Journal of Agricultural Research 53: 151-173.

Gault, R.R.; Peoples, M.B.; Turner, G.L.; Lilley, D.M.; Brockwell, J.; Bergersen, F.J. 1995. Nitrogen fixation by irrigated lucerne during the first three years of establishment. Australian Journal of Agricultural Research 46: 1401-1425.

Greenwood, P.B.; Sheath, G.W. 1982. Suitability of some pasture species within sub-humid areas of Otago 2. Legumes. New Zealand Journal of Experimental Agriculture 10: 371-376. 
Harris, P.B.; McNaught, K.J.; Lynch, P.B. 1967. The main effects and interactions of nutrients on the growth of irrigated lucerne. New Zealand Journal of Agricultural Research 9: 653-690.

Hoglund, J.H.; Dougherty, C.T.; Langer, R.H.M. 1974. Response of irrigated lucerne to defoliation and nitrogen fertiliser. New Zealand Journal of Experimental Agriculture 2: 7-11.

Janson C.G. 1975. Irrigation of lucerne in its establishment year. New Zealand Journal of Experimental Agriculture 3: 223-228.

Mills, A.; Smith, M.C.; Lucas, R.J.; Moot, D.J. 2008. Dryland pasture yields and botanical composition over 5 years under sheep grazing in Canterbury. Proceedings of the New Zealand Grassland Association 70: 37-44

Moot, D.J. 2012. An overview of dryland legume research in New Zealand. Crop and Pasture Science 63: 726-733.

Moot, D.J.; Pollock, K.M.; Lewis, B. 2012. Plant population, yield and water use of lucerne sown in autumn at four sowing rates. Proceedings of the New Zealand Grassland Association 74: 97-102.
Morton, J.D.; Roberts, A.H.C. 2009. Fertiliser use on New Zealand sheep and beef farms. New Zealand Fertiliser Manufacturer's Research Association, Auckland, New Zealand. 40p.

Risk, W.H.; Smith, L.C. 1992. Fertiliser requirements of lucerne cut for hay in northern Southland. Proceedings of the New Zealand Grassland Association 54: 59-63.

Sinclair, A.G.; Johnstone, P.D.; Smith, L.C.; Roberts, A.H.C.; O'Connor, M.B.; Morton, J.D. 1997. Relationship between pasture dry matter yield and soil Olsen P from a series of long term field trials. New Zealand Journal of Agricultural Research 40: 559-567.

Stephen, R.C. 1970. Responses by lucerne and associated volunteer species to applied fertilisers in North Canterbury. Proceedings of the New Zealand Grassland Association 32: 117-126. 